\title{
Primary Laryngeal Amyloidosis: A Case Report
}

\author{
Devkumar Rengaraja, Mohan Jagade, Vitthal Kale, Arpita Singhal, Kiran Kulsange, Karthik Rao, \\ Pallavi Gupta, Radhika Sonate, Amol Hekare, Chinmayee Hebbar
}

Department of ENT, Grant Government Medical College and Sir JJ Groups of Hospital, Mumbai, India

Email:devkumar16@gmail.com

How to cite this paper: Rengaraja, D., Jagade, M., Kale, V., Singhal, A., Kulsange, K., Rao, K., Gupta, P., Sonate, R., Hekare, A. and Hebbar, C. (2017) Primary Laryngeal Amyloidosis: A Case Report. International Journal of Otolaryngology and Head \& Neck Surgery, 6, 1-5.

http://dx.doi.org/10.4236/ijohns.2017.61001

Received: November 2, 2016

Accepted: January 6, 2017

Published: January 9, 2017

Copyright $\odot 2017$ by authors and Scientific Research Publishing Inc. This work is licensed under the Creative Commons Attribution International License (CC BY 4.0).

http://creativecommons.org/licenses/by/4.0/

\begin{abstract}
Amyloidosis is a benign, indolent condition which presents with an abnormal deposition of extracellular protein in various organs of the body. It usually presents with hoarseness of voice to an otolaryngologist. A sits clinical appearance mimics an early laryngeal cancer. It remains a diagnostic challenge to the clinician. It is essential to differentiate a primary laryngeal amyloidosis from malignancy to have a holistic approach towards the management of the disease. Here in this article, a case is reported in order to have a better outlook about this rare condition and to differentiate it from laryngeal malignancy for an effective management and cure.
\end{abstract}

\section{Keywords}

Laryngeal Amyloidosis, Amyloid, Localized Amyloidosis

\section{Introduction}

Primary laryngeal amyloidosis is a rare condition accounting for only $1 \%$ of all benign laryngeal tumors [1]. Amyloidosis is a benign, slowly progressive condition characterized by deposition of abnormal extracellular protein in various organs in the body [2]. It may be either systemic or localized to an organ. Although the etiopathogenesis of the condition is unclear, in the localized type it is hypothesized that the extracellular protein (the monoclonal light chain deposits) is synthesized locally and deposited unlike the systemic amyloidosis [3]. Primary laryngeal amyloidosis is rare, usually seen in the $4^{\text {th }}$ to $6^{\text {th }}$ decade of life, with a male to female preponderance of 2:1.4 [4] [5]. Patients with laryngeal amyloidosis are usually present with the complaints of hoarseness of voice, dyspnea or stridor requiring emergency tracheostomy. It may rarely be associated with dysphagia [2]. Its clinical appearance almost resembles an early laryngeal malignancy. The definitive diagnosis is achieved by histopathological report of the biopsied specimen, which confirms the presence of amyloid deposits staining 
positive for Congo red with characteristic apple green bi-refringence in polarized light under electron microscopy.

\section{Case Report}

A 56-year-old male patient, teacher by occupation for the last 15 years, nonsmoker, presented to the ENT out-patient department of GRANT GOVT MEDICAL COLLEGE with complaints of hoarseness of voice and voice fatigue since 2 years, which had a gradual progression. There were no complaints of any difficulty in breathing or swallowing, blood in sputum or vomitus. There was no history of any laryngeal trauma or intubation. Patient didn't have any other significant medical history or any history of substance abuse. On examination, there was no abnormality in the oral cavity and physical examination of neck was within normal limits. Indirect laryngoscopy was done with a $70^{\circ}$ Hopkins rod which revealed a non-ulcerative smooth nodular lesion in the supraglottic region, well restricted to both sides of the false vocal cords and ventricles, not involving the true cords and mobility of the vocal cords was well preserved (Figure 1). CT scan was done which revealed an ill-defined heterogeneously enhancing mass lesion on the false vocal cords with freely mobile true cords (Figure 2). Definite diagnosis was made on histopathological examination for which biopsy was taken under general anesthesia. The biopsied specimen revealed an eosinophilic acellular stromal proliferation which stained to be Congo red Positive showing apple green birefringence in polarized light suggestive of amyloidosis (Figure 3). Systemic examination was done to rule out systemic amyloidosis and multiple myeloma. Biopsy was taken from the abdominal fat pad which revealed to be negative for amyloid. Urine examination was done and reported to be negative for Bence jones protein and was within normal limits. Routine blood

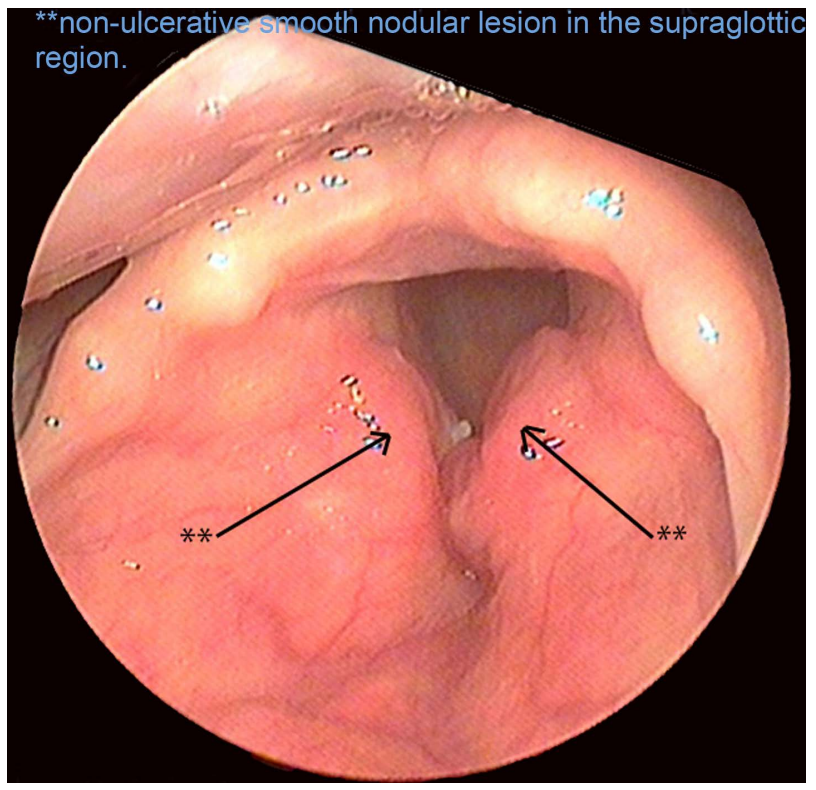

Figure 1. Indirect laryngoscopy: non-ulcerative smooth nodular lesion in the supraglottic region. 


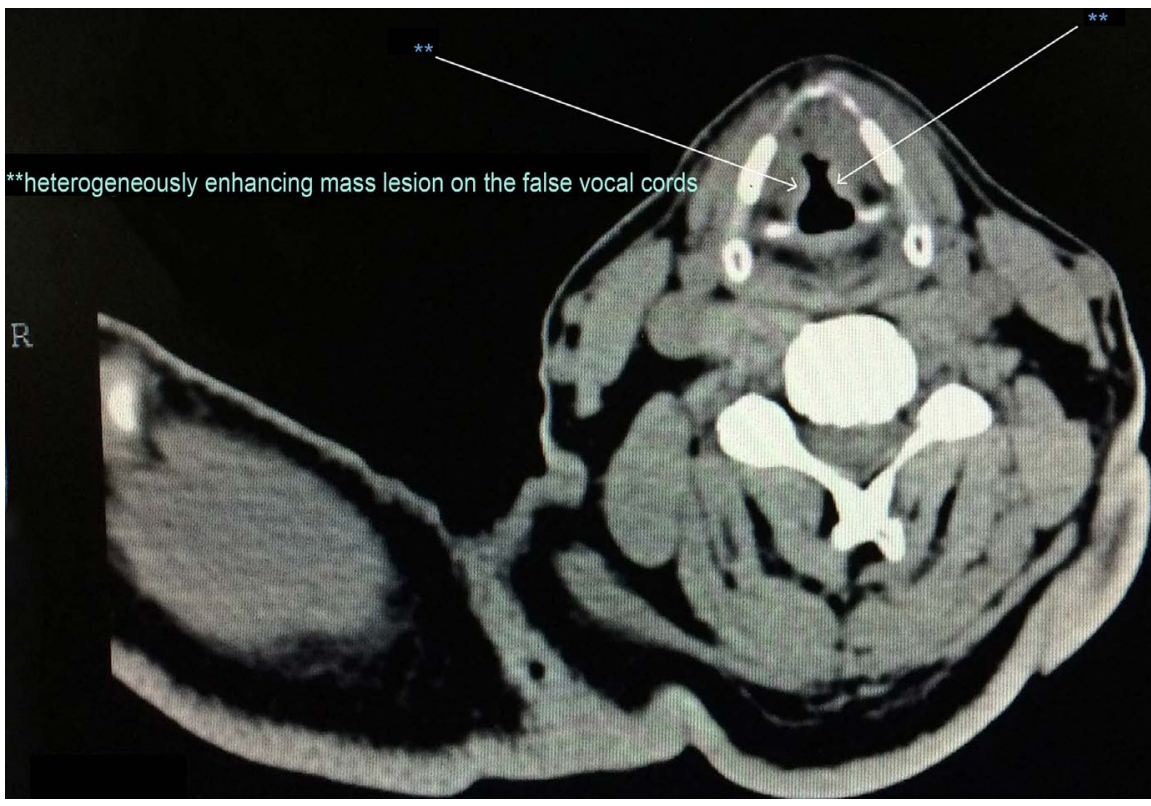

Figure 2. CT scan: heterogeneously enhancing mass lesion on the false vocal cords.

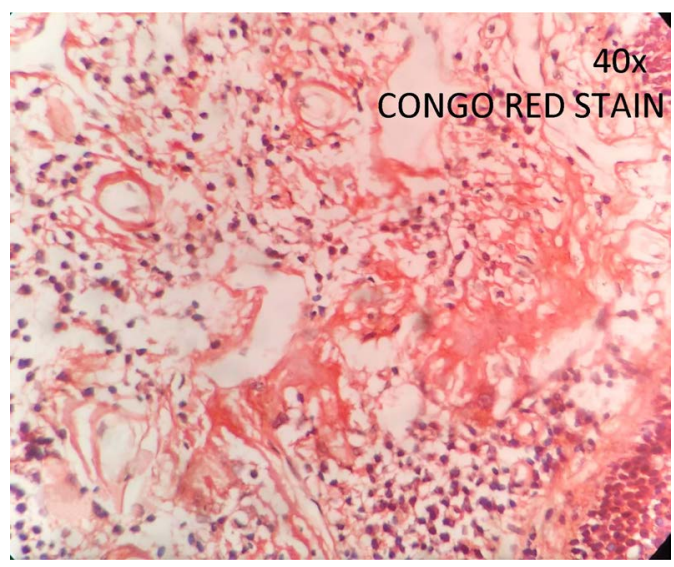

Figure 3. Histopathological slide: apple green birefringence in polarized light.

reports viz. complete blood counts, liver function tests, renal function test, serum protein electrophoresis were all within normal limits. After all these tests patient was diagnosed to be a case of primary amyloidosis. Surgical excision of the lesion was done under general anesthesia using microlaryngeal scopy with $\mathrm{CO}_{2}$ laser. Postoperative period was uneventful. Patient was advised voice rest for 48 hrs and was discharged. On follow up after 3 months patient had good normal voice quality and was advised regular follow up every 6 monthly.

\section{Discussion}

Amyloidosis is a metabolic disorder characterized by an abnormal deposition of the extracellular protein in various tissues of the body. Amyloidosis may be localized to a specific organ or may be generalized to various systemic organs [2]. The cause for localized laryngeal amyloidosis is unknown, it is hypothesized that 
it may be because of an inflammatory cell reaction of plasma cells to the antigens present [6] or the inability of the body to clear the monoclonal light chains produced by the mucosa associated lymphoid tissue [4]. The amyloid deposition leads to an alteration of the structure and hampers the function of the organ [7]. Primary laryngeal amyloidosis usually presents with hoarseness of voice, cough, dyspnea, sometimes even dysphagia. In a primary laryngeal amyloidosis, it is usually restricted to the ventricles and false cords, rarely involving the true cords [8]. The clinical appearance closely resembles that of laryngeal malignancy, thus differentiating such lesions from malignancy is essential for an effective management of the case. CT scan or MRI are useful investigation in knowing the extent of the disease. MRI is superior to CT as the amyloid deposits has intermediate $\mathrm{T} 1$ weighted and low T2 weighted intensity [9]. The definite diagnosis is achieved by tissue biopsy followed by the histopathological examination. The biopsied specimen reveals an eosinophilic acellular stromal proliferation which stains Congo red positive showing apple green birefringence in polarized light suggestive of amyloidosis. Prior to labeling a primary localized laryngeal amyloidosis, it is essential to rule out the systemic involvement and other associated disorders like multiple myeloma and lymphoma. The investigations required are serum and urine electrophoresis, electrocardiogram, complete blood count, liver function test, renal function test and abdominal fat pad biopsy [3]. Surgery is the main stay of treatment in Laryngeal amyloidosis using $\mathrm{CO}_{2}$ laser excision. Though, the choice of laser or micro laryngeal forceps and scissors depends on the experience of the surgeon and his/her convenience. For a better postoperative outcome, $\mathrm{CO}_{2}$ Laser excision is superior due to its accuracy, healing and preservation of function [10]. Medical management in the form of corticosteroids and radiotherapy has been tried but didn't give any promising results [10]. The disease has a slow progression, but may recur which might require repeated excision requiring a regular 6 monthly follow-up. Despite the clinical resemblance of the disease to early laryngeal malignancy, a specific diagnosis of the case is mandatory for its appropriate management and cure of the disease. Thus, Laryngeal amyloidosis should be kept as a differential diagnosis.

\section{Conclusion}

Laryngeal mass is a common presentation in patients presenting to an ENT clinic with hoarseness of voice. A systematic and thorough approach is mandatory for the effective management of such cases. Laryngeal amyloidosis should be kept as a differential diagnosis when we deal such patients. Histopathology is the diagnostic investigation and ruling out the involvement of other systems for an appropriate management is essential.

\section{References}

[1] Biewend, M.L., Menke, D.M. and Calamia, K.T. (2006) The Spectrum of Localized Amyloidosis: A Case Series of 20 Patients and Review of the Literature. Amyloid, 13, 135-142. https://doi.org/10.1080/13506120600876773 
[2] Yiotakis, I., Georgolios, A., Charalabopoulos, A., Hatzipantelis, P., Golias, C., Charalabopoulos, K. and Manolopoulos, L. (2009) Primary Localized Laryngeal Amyloidosis Presenting with Hoarseness and Dysphagia: A Case Report. Journal of Medical Case Reports, 3, 1. https://doi.org/10.4076/1752-1947-3-9049

[3] Ma, L., Bandarchi, B., Sasaki, C., Levine, S. and Choi, Y. (2005) Primary Localized Laryngeal Amyloidosis: Report of 3 Cases with Long-Term Follow-Up and Review of the Literature. Archives of Pathology \& Laboratory Medicine, 129, 215-218.

[4] Neuner, G.A., Badros, A.A., Meyer, T.K., Nanaji, N.M. and Regine, W.F. (2012) Complete Resolution of Laryngeal Amyloidosis with Radiation Treatment. Head \& Neck, 34, 748-752. https://doi.org/10.1002/hed.21626

[5] Gallivan, G.J. and Gallivan, H.K. (2010) Laryngeal Amyloidosis Causing Hoarseness and Airway Obstruction. Journal of Voice, 24, 235-239.

https://doi.org/10.1016/j.jvoice.2008.07.006

[6] Benning, S., Technau-Ihling, K., Fisch, P., Fradis, M., Schipper, J. and Maier, W. (2004) Amyloid Tumor of the Larynx Associated with Plasma Cell Infiltration: Differential Diagnosis. Ear, Nose and Throat Journal, 83, 839-844.

[7] Oğuz, H., Safak, M.A., Demirci, M. and Arslan, N. (2006) Familial Primary Localized Laryngeal Amyloidosis in Two Sisters. Kulak Burun Bogaz Ihtisas Dergisi: $K B B=$ Journal of Ear, Nose, and Throat, 17, 283-286.

[8] Vasquez de la Iglessia, F., Sanchez-Fernandis, N., Martinez, J., Ruba San Miguel, D., Rama Lopez, J. and Fernandez Gonzales, S. (2006) Amyloidosis in the ORL Field. Acta Otorrinolaringológica Española, 57, 145-148.

[9] Hegarty, J.L. and Rao, V.M. (1993) Amyloidoma of the Nasopharynx: CT and MR Findings. American Journal of Neuroradiology, 14, 215-218.

[10] Behranwala, K.A., Asgar, B.A., Borges, A. and Marfatia, P.T. (2004) Laser in Treatment of Laryngeal Amyloidosis. Indian Journal of Otolaryngology and Head and Neck Surgery, 56, 46-48.

\section{Submit or recommend next manuscript to SCIRP and we will provide best service for you:}

Accepting pre-submission inquiries through Email, Facebook, LinkedIn, Twitter, etc. A wide selection of journals (inclusive of 9 subjects, more than 200 journals)

Providing 24-hour high-quality service

User-friendly online submission system

Fair and swift peer-review system

Efficient typesetting and proofreading procedure

Display of the result of downloads and visits, as well as the number of cited articles

Maximum dissemination of your research work

Submit your manuscript at: http://papersubmission.scirp.org/

Or contact ijohns@scirp.org 